\title{
Program Pengabdian Guru dan Tata Usaha TK/RA di Batam
}

\author{
Dwi Ely Kurniawan ${ }^{1 *}$, Afdhol Dzikri \\ ${ }^{1}$ Teknik Informatika, Politeknik Negeri Batam, Batam, Indonesia \\ ${ }^{2}$ Teknik Multimedia Jaringan, Politeknik Negeri Batam, Batam, Indonesia \\ Email Korespondensi: dwialikhs@ polibatam.ac.id
}

Received July 26, 2021; Revised August 8, 2021; Accepted August 9, 2021

\begin{abstract}
Abstrak
Guru dan tata usaha merupakan ujung tombak dalam pengembangan peserta didik. Namun, banyak guru yang masih mengalami kesulitan mengikuti perkembangan berbagai metode baru dalam pembelajaran terutama pada anak PAUD. Sistem inventarisasi data di sekolahpun masih menggunakan cara konvensional (mencatat di kertas). Guru PAUD dituntut untuk selalu kreatif dalam membuat media pembelajaran yang tepat sesuai perkembangan anak. Staf administrasi (TU) dituntut untuk mengikuti perkembangan teknologi informasi. Metode pelaksanaan dalam program ini meliputi tahap persiapan, tahap pelaksanaan dan tahap evaluasi. Tahap persiapan membuat kesepakatan untuk mengalokasikan waktu dan tempat selama program pelatihan dan pendampingan. Selain itu menganalisis kebutuhan dengan melihat spesifikasi perangkat yang sudah ada dan sistem yang sudah berjalan. Tahap pelaksanaan berupa program pelatihan dan pendampingan untuk guru dan tata usaha di Batam. Pada tahap evaluasi, dievaluasi program pelatihan dan pendampingan secara keseluruhan. Harapannya setelah pelatihan dan pendampingan, guru TK / RA dan tata usaha memiliki kemampuan dalam penguasaan media IT maupun online untuk lebih kreatif dan inovatif dalam menyiapkan pembelajaran yang sesuai dengan perkembangan anak. Selain itu dapat terjalin kerjasama mitra secara kontinuitas.
\end{abstract}

Kata Kunci: Guru dan TU; TIK; Administrasi perkantoran; TK/RA; Batam

\begin{abstract}
Teachers and administration are the spearheads in the development of students. However, many teachers still have difficulty following the development of various new methods of learning, especially in PAUD children. The data inventory system in schools still uses conventional methods (taking notes on paper). PAUD teachers are required to always be creative in making learning media that is appropriate for children's development. Administrative staff (TU) are required to keep abreast of information technology. The method of implementation in this program includes the preparation, implementation and evaluation stages. The preparation stage makes an agreement to allocate time and place during the training and mentoring program. Besides analyzing the needs by looking at the specifications of existing devices and systems that are already running. The implementation phase is in the form of training and mentoring programs for teachers and administrators in Batam. At the evaluation stage, the overall training and mentoring program was evaluated. The hope is that after training and mentoring, TK / RA teachers and administration have the ability to master IT and online media to be more creative and innovative in preparing learning that is suitable for children's development. In addition, partnerships can be established continuously.
\end{abstract}

Keywords : Teacher and staff; ICT; Office administration; Kindergarten education; Batam

\section{PENDAHULUAN}

Pembelajaran Anak Usia Dini (PAUD) harus dilakukan secara menyenangkan agar mendapatkan hasil yang maksimal. Belajar sambil bermain dapat dilakukan guru kepada anak usia dini untuk mengembangkan kreativitas anak [1]. Banyak sekolah yang masih berkutat dengan media pembelajaran konvensional seperti hanya mengandalkan buku dan pensil semata. Buku pelajaran dan majalah (lembar kerja) menjadi andalan guru dalam proses belajar mengajar [2]. Padahal setiap anak memiliki karakter yang berbeda-beda seperti visual, audio, dan kinestetik [3]. Jika guru memanfaatkan media pembelajaran secara monoton maka ketertarikan anak 
untuk belajar sangatlah minim. Oleh karena itu guru PAUD dituntut untuk selalu kreatif dalam membuat media pembelajaran yang tepat sesuai perkembangan anak [4].

Sementara ini fenomena yang berkembang games sudah menjamur di berbagai kalangan mulai dari balita sampai dewasa [5]. Anak balita sudah mulai pandai dan sangat tertarik menggunakan gadget. Games edukasi masih minim di kalangan anak-anak karena banyak anak yang bermain games tanpa bimbingan atau seleksi dari orang tua maupun orang dewasa lainnya. Untuk itu pemanfaatan games edukasi dapat dijadikan sebagai salah satu cara yang efektif dalam melakukan proses belajar mengajar pada anak. Prinsip belajar sambil bermain ataupun belajar yang menyenangkan dapat diterapkan pada games edukatif karena anak tanpa sadar sudah melakukan proses pembelajaran dalam permainan yang dilakukannya [2]. Hal ini dapat menjadi alternatif pilihan baik pada orang tua maupun tenaga pendidik untuk memberikan games yang sesuai dengan perkembangan dan kebutuhan anak-anak.

Penguasaan media TIK (Teknologi Informasi dan Komunikasi) sudah menjadi tuntutan bagi semua guru di setiap jenjang. Mulai dari tingkat Taman Kanak-kanak sampai Sekolah Lanjutan Menengah Atas semua memanfaatkan media berbasis TIK.

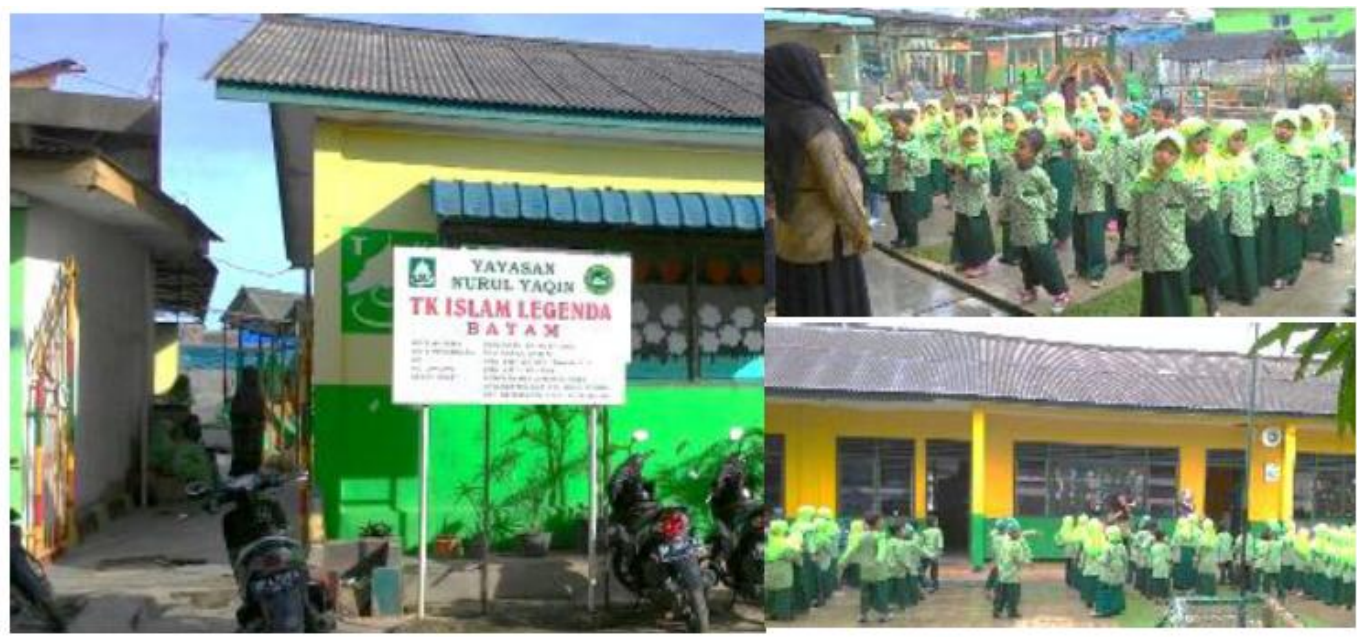

Gambar 1. Suasana TK Islam Legenda

TK Islam Legenda berlokasi di Kompleks Masjid Nurul Yaqin Blok K, Jl. Legenda Malaka, Baloi Permai, Batam Kota, Kota Batam yang berjarak -/+ $3 \mathrm{~km}$ dari Politeknik Negeri Batam. Siswa TK Islam Legenda yang terdaftar 70 orang dengan dibuka 5 kelas. TK Islam Legenda saat ini memiliki guru dan tata usaha masing sebanyak 6 guru dan 2 tata usaha dengan pendidikan paling tinggi lulusan SMA dan D3, serta sebagian dari mereka sedang melanjutkan pendidikan S1.

Beberapa guru dan tata usaha di TK Islam Legenda masih mengalami kesulitan dalam mengoperasikan aplikasi perkantoran seperti membuat dokumen dan mencetak laporan serta mengakses internet. Apalagi saat ini Direktorat Jendral Pendidikan Anak Usia Dini dan Pendidikan Masyarakat di bawah Kementrian Pendidikan dan Kebudayaan telah menginstruksikan bahwa sekolah PAUD wajib untuk melaporkan Data Pokok Pendidikan PAUD-DIKMAS (DAPODIK) dan untuk sekolah dibawah Kementrian Agama dilaporkan ke sistem EMISPENDIS secara online seperti pendataan peserta didik, lembaga, guru dan lain sebagainya secara terpusat.

Selain itu pelaksanaan test UKG (Ujian Kompetensi Guru) juga tidak luput dari pemanfaatan media online. Berdasarkan hasil ujian dari beberapa guru, mereka merasa kesulitan dalam mengoperasikan komputer, gugup dan merasa tidak terbiasa disamping kesulitan atau kemampuan dalam mengerjakan soal. Begitu pula pada penyiapan media pembelajaran, penilaian, dan lain sebagainya harus menggunakan media online. Oleh karena itu guru-guru yang masih minim penguasaan komputer dan pemanfaatan media TIK lainnya sangatlah perlu mendapat pelatihan untuk meningkatkan kemampuannya di bidang TIK. Minimal para guru tersebut sudah mahir mengoperasikan komputer dan aplikasi perkantoran. Kesulitan lain ketika diwawancara belum ada aplikasi untuk menangani SPP dan laporan keuangan secara baik. Hilangnya kartu bukti pembayaran sering kali terjadi, bahkan rekap pembayaran menjadi kendala terbesar. 


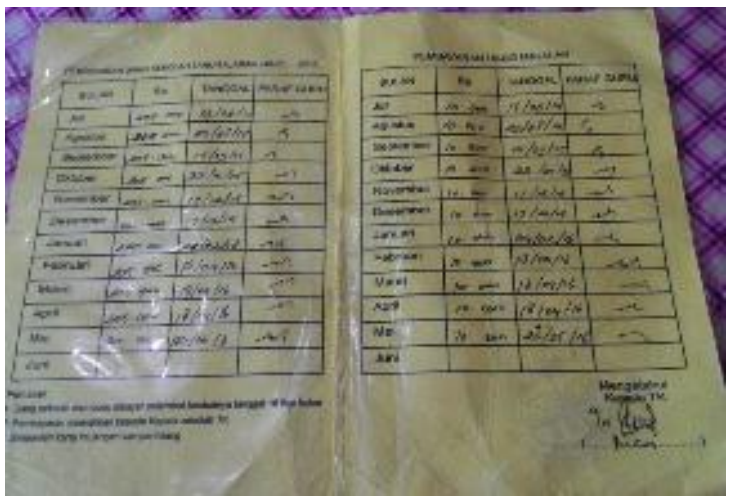

Gambar 2. Kartu Pembayaran SPP TK Islam Legenda

Berdasarkan uraian diatas sehingga perlu dilakukan kegiatan pendampingan, pelatihan dan keterampilan bagi para guru PAUD. Harapannya setelah pelatihan, guru PAUD memiliki kemampuan dalam penguasaan media TIK maupun online untuk lebih kreatif dan inovatif dalam menyiapkan pembelajaran yang sesuai dengan perkembangan anak serta mendukung dalam pendidikan. Selain itu bagi tata usaha memiliki kemampuan dalam mengoperasikan komputer, printer dan administrasi perkantoran.

Berdasarkan hasil wawancara dan diskusi dari permasalahan mitra dapat dikategorikan masalah yang muncul secara umum diantaranya sebagai berikut:

1) Guru dan Tata Usaha mengalami kesulitan dalam mengoperasikan komputer.

2) Guru dan Tata Usaha mengalami kesulitan dalam menggunakan aplikasi untuk mendukung administrasi perkantoran.

3) Guru dan Tata Usaha mengalami kesulitan dalam menggunakan internet dan media online lainnya.

4) Guru belum mampu menyediakan atau memanfaatkan media pembelajaran secara multivariatif berbasis TIK.

5) Tata Usaha mengalami kesulitan dalam melakukan pencatatan pembayaran SPP siswa.

Adapun program solusi yang akan ditawarkan adalah sharing, pelatihan dan pendampingan. Program sharing merupakan yang dilakukan dengan sharing terkait pengelolaan pembelajaran di kelas dan kebutuhankebutuhan keterampilan yang diperlukan mitra TK/RA di Batam. Program pelatihan, yakni pelatihan dasar mengoperasikan komputer (sistem operasi) [6], penanganan virus dan instalasi serta update antivirus, pelatihan mengoperasikan perangkat lunak office untuk surat-menyurat, laporan dan dokumen lainnya, pelatihan mengoperasikan perangkat lunak office untuk membuat laporan keuangan, jadwal, bagan struktur dan dasardasar basis data dan Pelatihan Internet dan Email untuk mendukung aktifitas perkantoran. Selain pelatihan juga ada pendampingan. Pendampingan dalam instalasi sistem operasi dan perangkat lunak office, Pendampingan kasus-kasus bekerja menggunakan perangkat lunak office, Pendampingan instalasi perangkat printer dan scanner.

Hasil dari sharing pengelolaan media pembelajaran TIK akan diberikan penyerahan aplikasi seperti: Aplikasi media pembelajaran Matematika; mengenal angka, Bahasa Inggris; mengenal kosa kata benda sekitar, media pembelajaran cinta tanah air (Pancasila). Implementasi menggunakan spesifikasi yang diakses menggunakan PC desktop maupun smartphone, berupa games, animasi 2D dan 3D menggunakan Augmented Reality[7] [8].

\section{METODE}

Metode dalam Program Kemitraan Masyarakat (PKM) meliputi tahap persiapan, tahap pelaksanaan dan tahap evaluasi. Tahap persiapan melakukan survei lokasi, diskusi dan wawancara untuk menggali permasalahan yang ada dan menganalisis kebutuhan dengan melihat spesifikasi perangkat yang sudah ada dan sistem yang saat ini sudah berjalan. Selain itu membuat kesepakatan untuk mengalokasikan waktu, tempat dan ruangan selama program pelatihan dan pendampingan. Tahap pelaksanaan berupa program pelatihan dan pendampingan untuk guru dan tata usaha di sekolah mitra TK Islam Legenda. Program pelatihan aplikasi perkantoran meliputi pelatihan Ms. Office Word, Ms. Excel, Ms. Power Point, Internet dan pembuatan email sesuai dengan kebutuhan mitra. 


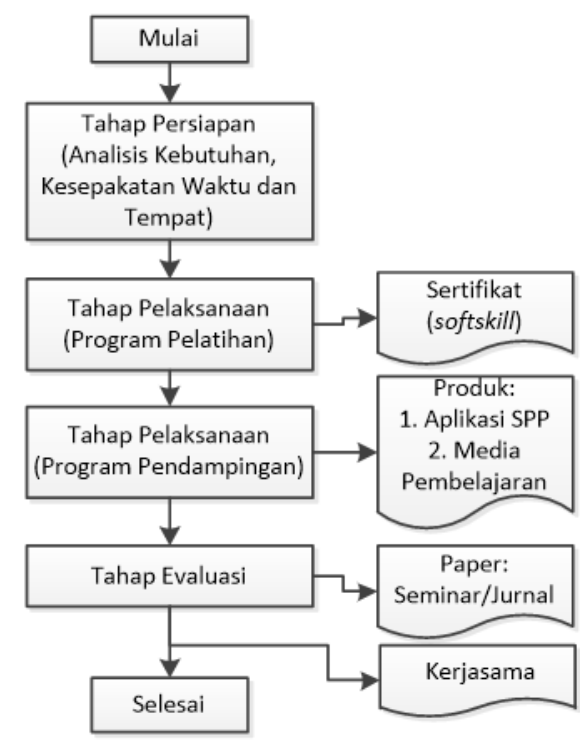

Gambar 3. Metode Pengabdian

Program pelatihan lain yakni instalasi dan konfigurasi perangkat printer serta sharing resource. Bagi peserta yang mengikuti program pelatihan diberikan ujian sesuai dengan Skema Komptensi KKNI. Sedangkan untuk program pendampingan meliputi implementasi media pembelajaran Matematika, Bahasa Inggris [9]. Selain itu program pendampingan dalam pembuatan aplikasi pembayaran SPP yang disesuaikan dengan analisis kebutuhan pengguna dan sistem yang berjalan. Pihak sekolah akan mendapatkan produk media pembelajaran dan aplikasi pembayaran SPP yang nantinya akan di evaluasi dalam implementasi tersebut.

Tabel 1. Solusi dan Bentuk Kegiatan

\begin{tabular}{llc}
\hline No & \multicolumn{1}{c}{ Solusi } & Bentuk Kegiatan \\
\hline 1 & Mengenalkan Program Aplikasi Microsoft Office dengan versi 2009 & \\
& dan 2010 keatas, baik untuk tipe data dan cara menyimpan diberbagai & \\
& versi.
\end{tabular}

2 Memberikan pelatihan dalam instalasi dan konfigurasi printer serta

Pelatihan TIK Office sharing printer

3 Memberikan pelatihan dalam penangan data yang terkena virus dan merecovery data yang hilang

$4 \quad$ Memberikan pelatihan instalasi dan update antivirus

5 Memberikan pelatihan dan pendampingan dalam membiasakan ujian dengan menggunakan komputer

6 Memberikan pelatihan dalam kasus membuat dokumen surat dan dokumen laporan

Memberikan pelatihan dalam membuat template berbagai surat

Memberikan pelatihan dalam mengetik cepat dan tombol short cut.

$7 \quad$ Memberikan pelatihan dalam membuat mail merge

8 Memberikan pelatihan dalam kasus membuat laporan keuangan

Memberikan pelatihan dalam membuat template laporan keuangan

Membuat pelatihan bagan struktur sekolah dengan Microsoft Office

9 Memberikan pelatihan dalam mencetak dokumen Excel sesuai dengan margin dan page layout kertas

Pelatihan dan pendampingan dalam studi kasus penerapan TIK dalam bekerja seharihari

Pelatihan dan pendampingan dalam studi kasus penerapan TIK dalam bekerja seharihari

10 Memberikan pelatihan dalam berselancar di internet

11 Memberikan pelatihan dalam pembuatan email instansi

Pelatihan menggunakan Internet dan Email

Memberikan pelatihan dalam mengirim email dan menyertakan 
lampiran

12 Memberikan pelatihan dan pendampingan dalam menginput data

sekolah ke sistem DAPODIK (https://dapo.paud- Pendampingan cara

dikmas.kemdikbud.go.id ) dan EMIS menginput data

(http://emispendis.kemenag.go.id)

13 Memberikan pelatihan dan pendampingan dalam membuat dokumen dan laporan program mengajar.

Pelatihan

dan

pendampingan

pembuatan laporan

15 Membuatkan media pembelajaran sesuai dengan pembelajaran di kelas seperti Matematika Berhitung, dan Bahasa Inggris.

16 Membuatkan media pembelajaran sesuai dengan karakter dan kebutuhan anak.

17 Memberikan produk media pembelajaran hasil karya Prodi Multimedia.

18 Membuat aplikasi pencatatan SPP

Memberikan pelatihan dalam penggunaan aplikasi pembayaran SPP siswa

19 Memberikan produk aplikasi pembayaran SPP siswa ke mitra sesuai dengan spesifikasi kebutuhan pelaporan Yayasan Sekolah mitra.

Partisipasi mitra menyediakan konsumsi selama pelaksanaan kegiatan pelatihan dan pendampingan, menyiapkan tempat, waktu dan ruangan. Selain itu untuk transportasi perjalanan ke lokasi kegiatan ditanggung oleh mitra. Selanjutnya tahap evaluasi, tahap ini mengevaluasi program pelatihan dan pendampingan secara keseluruhan. Setelah program pelatihan office, internet dan TIK nantinya dapat dievaluasi dengan adanya guru mampu menggunakan dan menerapkan perangkat TIK dan media pembelajaran serta mampu membuat suratmenyurat, dokumen, jadwal dan laporan keuangan menggunakan aplikasi perkantoran.

Keberlanjutan program PKM dilakukan dengan menjalin kerjasama ntara pihak mitra TK / RA di Batam dan Politeknik Negeri Batam khususnya Program Studi Multimedia dalam penerapan produk-produk multimedia pembelajaran. Kerjasama melibatkan mahasiswa dengan mendampingi dalam memproduksi berbagai multimedia pembelajaran yang disesuaikan dengan kebutuhan pembelajaran anak usia dini.

\section{HASIL DAN PEMBAHASAN}

Hasil dan luaran yang dicapai pada program PKM Guru dan Tata Usaha TK / RA di Batam secara rinci meliputi hasil pelaksanaan kegiatan; pelatihan, pendampingan dan sharing pengelolaan TK/RA mitra, serta luaran publikasi media cetak (koran), jurnal ilmiah dan seminar internasional.

Program Pelatihan TIK dan Office untuk guru dan TU mitra diantaranya adalah sebagai berikut.

1) Pelatihan dasar mengoperasikan komputer, instalasi sistem operasi, instalasi printer, penanganan virus dan update antivirus.

2) Pelatihan mengoperasikan perangkat lunak office word untuk surat-menyurat, laporan dan dokumen lainnya yang mendukung mitra TK/RA.

3) Pelatihan mengoperasikan perangkat lunak office excel untuk membuat laporan keuangan, jadwal, dan bagan struktur.

4) Pelatihan Internet, Google dan Email untuk mendukung aktifitas perkantoran. Secara kesuluruhan pelatihan yang diberikan kepada mitra dalam bentuk buku totorial materi pelatihan [10].

Kegiatan pelatihan dilaksanakan pada bulan Juni dan Juli 2018 saat kegiatan pembelajaran siswa TK/RA sedang libur kenaikan. Pelatihan diadakan di tempat mitra dan diundang ke Kampus Politeknik Negeri Batam. 

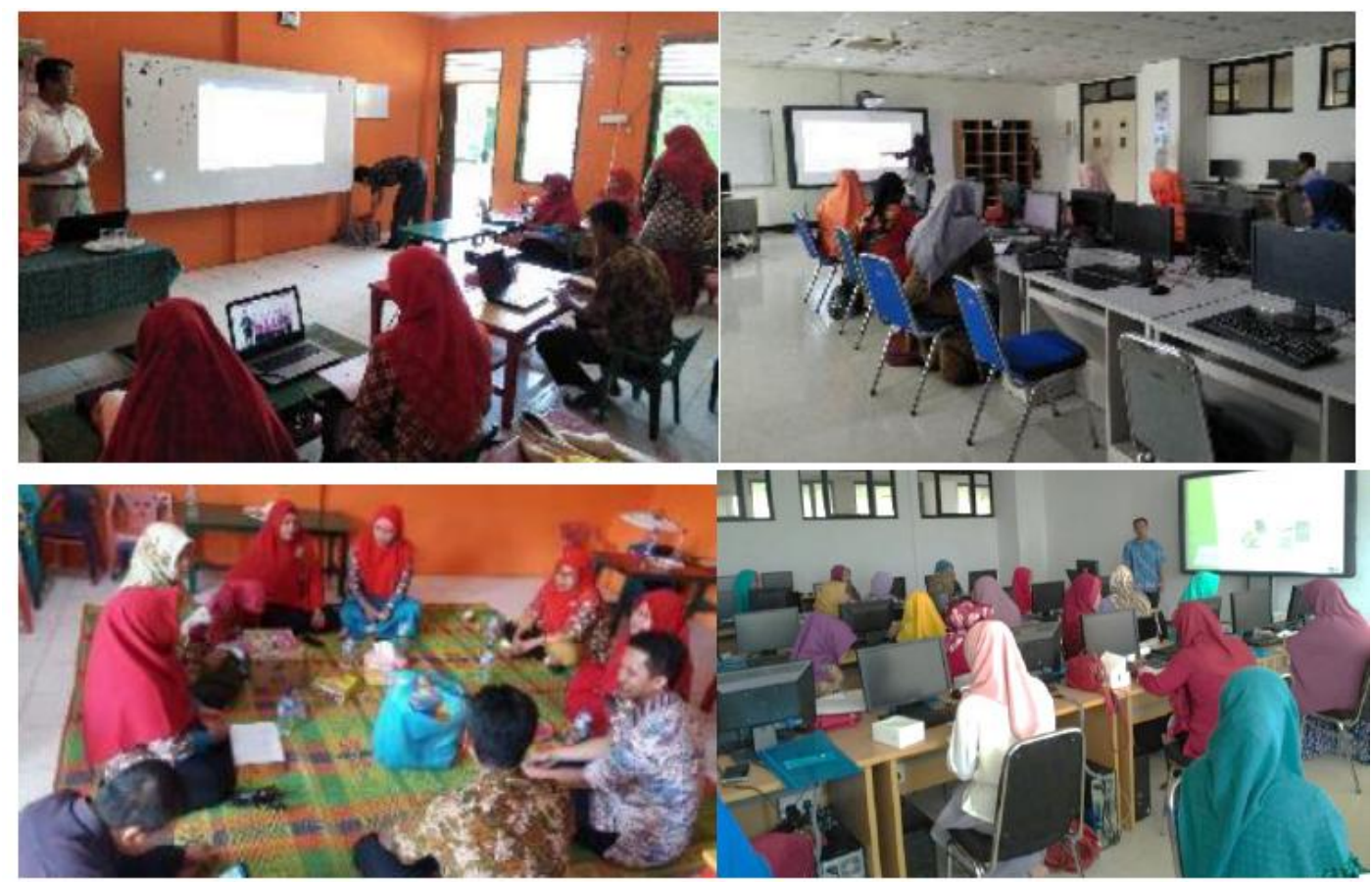

Gambar 4. Suasana Pelatihan dan Pendampingan di Tempat Mitra dan Kampus Polibatam

Program pendampingan yang dilaksanakan diantaranya melakukan pendampingan dalam penggunaan peralatan TIK seperti instalasi printer, instalasi sistem operasi dan pembuatan laporan, surat-menyurat dan pengelolaan keuangan menggunakan aplikasi Excel. Program pendampingan dilaksanakan dalam tiap bulannya secara insidental, sesuai dengan kebutuhan mitra. Kegiatan ini juga didukung dengan adanya pelatihan dan modul yang telah diberikan, harapannya guru dan TU dapat tuntas menguasai TIK.

Program sharing pembelajaran merupakan diskusi terkait permasalahan pembelajaran di kelas TK/RA yang saat ini berjalan. Pengabdian ini mencoba mengusulkan penggunaan media pembelajaran sebagai alternatif dalam pembelajaran anak usia 4-5 tahun atau TK/RA. Tentunya usulan ini memperhatikan keinginan, kebutuhan dan ketersediaan sarana dan prasana TIK dari pihak mitra.

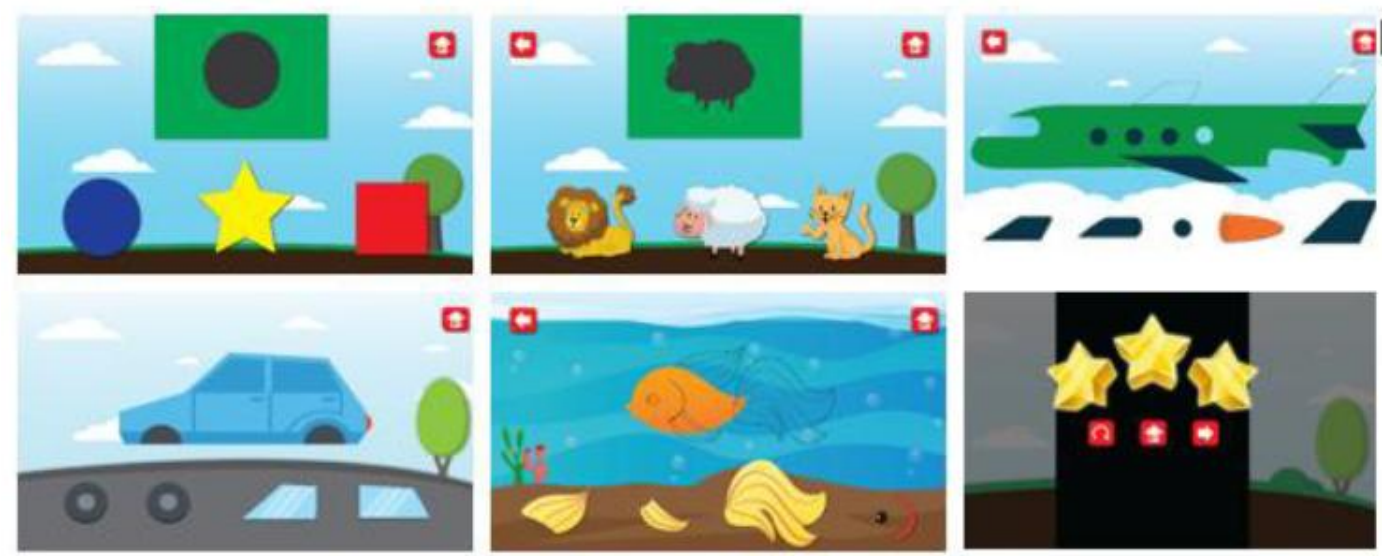

Gambar 5. Hasil Media Pembelajaran Mengenal Angka, Huruf, Bentuk dan Pola Untuk Anak 4-5 Tahun

Hasil dari sharing diantaranya; guru mengalami kesulitan mengikuti perkembangan metode belajar baru, salah satunya pemanfaatan media pembelajaran yang relevan sesuai dengan perkembangan teknologi saat ini. Bila merujuk pada akreditasi pendidikan juga dukungan dan pemanfaatan TIK menjadi poin dalam penilaian. Pendidikan anak usia 4-5 semestinya adalah belajar sambil bermain, maksudnya pembelajaran dilakukan secara menyenangkan, agar kreativitas anak berkembang. Adanya teknologi gadget yang berkembang hendaknya mampu diarahkan dengan baik dalam penggunaannya. Oleh karena itu untuk membantu proses pembelajaran siswa TK (usia 4-5 tahun) dalam mengembangkan kemampuan kognitif dalam mempelajari pengetahuan umum dan sains, konsep bentuk, pola, ukuran, dan warna perlu adanya media berbasis TIK, yakni memanfaatkan 
gadget untuk pembelajaran alternatif di kelas untuk mengenalkan dan mengarahkan agar tidak salah dalam penggunaannya. Sharing pembelajaran kemudian mencetuskan untuk membuat media pembelajaran untuk mengenalkan Matematika dan Bahasa Inggris dengan mengembangkan kognitif siswa melalui bentuk, pola, angka, ukuran dan warna. Berikut hasil dari pembuatan aplikasi media pembelajaran yang diberi nama Pandai.

Aplikasi Pandai memiliki halaman utama yang terdapat menu interaktif untuk mempelajari abjad, pola kecocokan, merakit bentuk, dan mewarnai objek tertentu [11]. Pengguna (siswa/guru) dapat mengklik, menarik dan menjatuhkan objek. Selain itu, ada juga beberapa tombol navigasi: tombol Beranda digunakan untuk kembali ke halaman utama, tombol Coba lagi untuk mengambil kembali latihan, tombol Penjelasan untuk melihat jawaban penjelas untuk sebuah pertanyaan, dan tombol Berikutnya dan Sebelumnya untuk pergi ke halaman berikutnya dan sebelumnya masing-masing. Selain media pembelajaran tersebut juga membuat media pembelajaran berbasis Augmented Reality untuk mengenalkan Pancasila. Berikut aplikasinya.
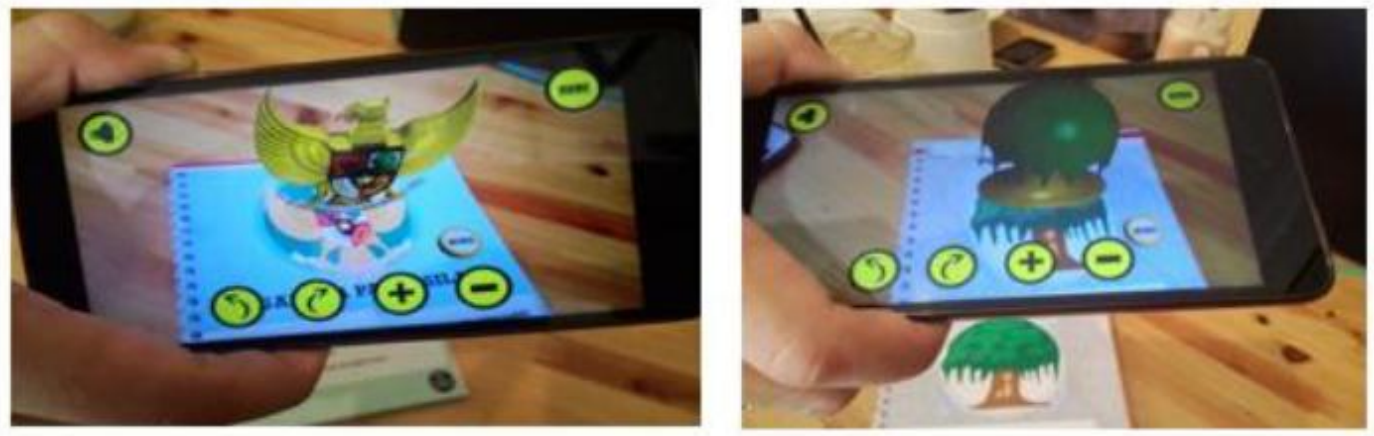

Gambar 6. Hasil Media Pembelajaran Mengenal Pancasial Berbasis Augmented Reality

Augmented Reality adalah teknologi yang menggabungkan benda maya 2D atau 3D ke dalam sebuah lingkungan nyata untuk memproyeksikan benda-benda maya tersebut secara nyata (realtime) [7]. Aplikasi pembelajaran Pancasila dapat menampilkan satu object 3D animasi dari lambang-lambang Pancasila [12]. Harapannya dengan mengenalkan lambang Pancasila siswa mampu mengenal dan mencintai Bangsa Indonesia yang Berbhenika Tunggal Ika.

\section{KESIMPULAN}

Kesimpulan dan saran yang diperoleh setelah melakukan program PKM Guru dan TU TK/RA di Batam adalah sebagai berikut :

1) Program pelatihan yang telah dilaksanakan telah cukup membekali guru dan TU dalam penggunaan perangkat TIK seperti Ms Office Word dan Excel dalam mendukung kegiatan surat-menyurat, pelaporan keuangan, serta penggunaan printer untuk mecetak berbagai variasi pelaporan dengan jenis dokumen yang berbeda

2) Program pelatihan internet, google dan email membekali guru dan TU dalam berselancar mencari informasi, melakukan kirim surat menggunakan email, mengentri data DAPODIK.

3) Program pendampingan memberikan ketuntasan dalam menguasai perangkat TIK dalam berbagai masalah dan kebutuhan mitra dalam PKM.

4) Program sharing pembelajaran memberikan alternatif solusi media pembelajaran berupa matematika pandai dan aplikasi pengenalan lambang pancasila untuk mendukung cinta tanah air dan bangsa Indonesia.

\section{DAFTAR PUSTAKA}

[1] Y. Nurdiani, "Penerapan Prinsip Bermain Sambil Belajar Dalam Mengembangkan Multiple Inteligencia Pada Pendidikan Anak Usia Dini (Study Kasus Di PAUD Daarul Piqri Kelurahan Leuwigajah Cimahi Selatan),” Empower. J. Ilm. Progr. Stud. Pendidik. Luar Sekol., vol. 2, no. 2, pp. 85-93, 2013.

[2] D. Ely Kurniawan, A. Dzikri, H. Widyastuti, E. Sembiring, and R. Tiurma Manurung, "Smart mathematics: a kindergarten student learning media based on the drill and practice model," J. Phys. Conf. Ser., vol. 1175, p. 012037, Mar. 2019, doi: 10.1088/1742-6596/1175/1/012037.

[3] H. Khairi, "Karakteristik perkembangan anak usia dini dari 0-6 tahun," J. Warn., vol. 2, no. 2, pp. 15-28, 2018.

[4] K. Dewi, "Pentingnya Media Pembelajaran untuk Anak Usia Dini," Raudhatul Athfal, vol. 1, 2017.

[5] M. Fadlillah and others, Buku ajar bermain \& permainan anak usia dini. Prenada Media, 2019.

[6] D. E. Kurniawan, Modul Praktikum Sistem Operasi. 2015.

[7] D. E. Kurniawan and A. Dzikri, Augmented reality : praktikum dan penerapan dalam visual objek. Polibatam Press, 2020 . 
[8] D. E. Kurniawan, P. Silalahi, and A. Pratiwi, "ARtrace: Augmented Reality for Student's Fine Motor Learning," 2019 2nd Int. Conf. Appl. Eng., pp. 1-5, Oct. 2019, doi: 10.1109/ICAE47758.2019.9221724.

[9] S. B. Aji et al., "Pembuatan Media Belajar English For Ecotourism Untuk Masyarakat Hinterland," J. Pengabdi. Kpd. Masy., vol. 2, no. 1, pp. 43-51, 2020.

[10] N. Z. Janah, Y. Rokhayati, D. E. Kurniawan, and M. F. Muvariz, "Electronic School Books Dissemination Application for Batam Hinterland Schools," Adv. Sci. Lett., vol. 24, no. 12, pp. 9739-9744, Dec. 2018, doi: 10.1166/asl.2018.13128.

[11] A. Prabowo, A. H. Thohari, and D. E. Kurniawan, "Development of Interactive Learning Application for Vocational High School," 2019 2nd Int. Conf. Appl. Eng., pp. 1-4, Oct. 2019, doi: 10.1109/ICAE47758.2019.9221674.

[12] Y. Arifin and A. Dzikri, "Pembuatan Film Animasi 2d Guna Pengenalan Sila Dalam Pancasila," J. Digit. Educ. Commun. ARTS, vol. 3, no. 01, pp. 18-29, 2020. 